\title{
Pastoraat en jeugtrauma, die 'sondebokmodel', en Jesus as ROlmodel
}

\author{
Authors: \\ Annelize Endres ${ }^{1}$ \\ Yolanda Dreyer ${ }^{1}$
}

\begin{abstract}
Affiliations:
${ }^{1}$ Departement Praktiese

Teologie, Universiteit van

Pretoria, Suid-Afrika
\end{abstract}

\section{Correspondence to:}

Yolanda Dreyer

e-mail:

yolanda.dreyer@up.ac.za

\section{Postal address:}

Departement Praktiese

Teologie, Universiteit van

Pretoria, Lynnwoodweg,

Hatfield 0083, Suid-Afrika

\section{Keywords:}

getraumatiseerde adolessente; emosionele trauma; posttraumatiese stressindroom; geweld; emosionele ontwikkeling

\section{Dates:}

Received: 04 May 2009

Accepted: 06 June 2009

Published: 14 Aug. 2009

How to cite this article: Endres, A. \& Dreyer, J., 2009, 'Pastoraat en jeugtrauma, die "sondebokmodel", en Jesus as rolmodel', HTS Teologiese Studies/ Theological Studies 65(1), Art. \#196, 6 pages. DOI: 10.4102/hts.v65i1.196

\section{This article is available} at:

http://www.hts.org.za

\section{Nota:}

Hierdie artikel is een van twee verwerkings van dele uit die PhDproefskrif deur Annelize Endres onder leiding van prof. dr Yolanda Dreyer, voorgelê en aanvaar in die Departement Praktiese Teologie, Fakulteit Teologie, Universiteit van Pretoria (2009)

\section{(C) 2009. The Authors.} Licensee: OpenJournals Publishing. This work is licensed under the Creative Commons Attribution License.

\section{ABSTRACT}

Pastoral care with traumatised youth, the 'scapegoat' model, and Jesus as role model Existing research shows that adolescents are victimised and traumatised more often than adults. Many a time it is left to pastoral counsellors to assist such traumatised youth to overcome such experiences. This article therefore aims to empower pastors in this task with reference to the insights of René Girard. As violence is inherent to traumatic experiences, two aspects of Girard's insights are pertinent. Girard's notions of imitation with regard to violence, as well as the scapegoat ritual can be useful to pastors who want to guide adolescents through their trauma. Girard's contribution has been widely acknowledged and used by theologians in their hermeneutical and theological endeavours. This article now applies these insights to the field of Practical Theology. In theology, Jesus has become both the 'role model' and the 'scapegoat'. This article applies both these aspects of Jesus' life to pastoral care with traumatised youth.

\section{INLEIDING}

Kinders en adolessente word meer dikwels as volwassenes getraumatiseer. In Amerika het die Departement Justisie in 1993 reeds navorsingsresultate hieroor bekend gemaak (Reinherz, Giaconia, Lefkowitz, Pakiz \& Frost 1993:60). Hierdie navorsing het op adolessente tussen die ouderdom van 12 en 17 gekonsentreer, en is in 11 state sowel as die Distrik Columbia uitgevoer. Die navorsing het bevind dat hierdie jeugdige portuurgroep vyf keer meer dikwels die slagoffers van geweld is as persone bo die ouderdom van 35. Die geweld sluit verkragting, roof, en sowel fisieke as emosionele aanranding in. Volgens genoemde verslag (vgl. U.S. Department of Justice 1973-2006) was die helfte van die vroue wat in 1992 in Amerika verkrag is, jonger as 18 jaar. Hierdie studie het ook getoon dat onder 386 arbeiders 6,3\% van 17-jariges teenoor 5\% van volwassenes aan posttraumatiese stressindroom ly (Reinherz et al. 1993:60).

Van der Kolk (1985:365-370), 'n wêreldkundige op die gebied van trauma, het op sy beurt onder Viëtnamese veterane met posttraumatiese stressimptome navorsing gedoen. Posttraumatiese stres is die herlewing van ' $n$ traumatiese gebeurtenis of voorval oor ' $n$ lang tydperk, en tree gewoonlik in nadat ' $n$ individu aan die een of ander vorm van trauma blootgestel of die slagoffer van geweld of misdaad was. Van der Kolk (1985:365-370) bevind dat dié simptome in 'n groter mate voorkom by soldate wat jonger was as die kontrolegroep toe hulle tot die oorlog toegetree het (18,3 jaar teenoor 23,8 jaar oud).

Die kerk het 'n roeping om die evangelie van God aan stukkende jongmense en gemeenskappe te bedien. Soos wat die kerk dié rol in bogenoemde Amerikaanse gemeenskappe vervul, doen hy dit ook in SuidAfrikaanse verband. Vir dié taak behoort die kerk en pastors opgelei te word om getraumatiseerde jongmense te begelei om weer heel te word. Adolessente voel reeds magteloos omdat hulle nie oor hulle liggame en emosies beheer het nie; trauma maak dié gevoel van magteloosheid en verwonding selfs erger.

Twee kernkonsepte uit René Girard se werk, naamlik 'nabootsende geweld' en die 'sondebokmeganisme', kan van groot nut wees vir pastors wat getraumatiseerde adolessente help om hulle trauma te verwerk, aangesien traumatiese gebeurtenisse dikwels gewelddadig is, en daar ná 'n traumatiese ervaring dikwels na 'n sondebok gesoek word. Indien Girard se sondebokteorie $(1965,1977,1978,1979,1986$, 1987, 1993) op die soteriologiese werk van Jesus toegepas word, kan die getraumatiseerde (gekruisigde) Jesus, eerder as die portuurgroep, as rolmodel (mimesis) in adolessente se soeke na identiteit beskou word. Girard het met hierdie teorie 'n beduidende invloed op die besinning oor godsdiens en geweld gehad.

\section{NABOOTSENDE GEWELD}

\section{Die funksie van 'n rolmodel}

Girard (1965) dui daarop dat konflik deur 'n 'nabootsende begeerte' ('mimetic desire') veroorsaak word. Mense leer om te begeer deur ander as modelle na te boots. Omdat mense van hulle eie gebreke bewus is, soek hulle eerder by ander na leiding om te bepaal wat waardevol is en wat nie, wie hulle behoort te wees, en wat hulle van die lewe wil hê. Hierdie konsep van nabootsende begeerte het Girard in die werke van Shakespeare (1564-1616), Cervantes (1547-1616) en Dostojevsky (1821-1881) ontdek. Volgens hom bestaan daar in hierdie werke ' $n$ verband tussen 'slagofferrituele' en nabootsende begeerte. Begeerte word mimeties (nabootsend) wanneer iemand iets begeer wat ook deur 'n ander persoon as waardevol beskou word. Só word die ander persoon 'n rolmodel: 'I desire to be like the person who desires what I now desire. I am thus attracted to this other person' (Girard 1965:15). Die rolmodel voel aanvanklik gevlei deur die bewondering, maar dié aanvanklike gevoel word vinnig oorgeneem deur die vrees om die voorwerp van begeerte te verloor. Wedywering ontstaan dus omdat albei partye dieselfde voorwerp begeer. Waar die rolmodel se denke nageboots word, bestaan daar harmonie. Waar die rolmodel se begeertes egter nageboots word, is die twee partye mededingers. Op dié manier kan mimesis dus tot meedoënlose wedywering lei.

In die vroegste tye was daar volgens Girard (1979:11) 'n gebrek aan kulturele beskermingsmeganismes, en daarom het hierdie gedeelde begeerte meermale tot geweld gelei. Vanweë die mens se mimetiese 
aard lei geweld tot meer geweld, en kring dit só al verder uit (Girard 1979:9-19). Mimetiese wedywering, en die geweld wat hierdie wedywering meebring, is ewe aansteeklik. Geweld op sigself is vir Girard (1986:34) mimeties van aard. As gevolg van die mens se mimetiese aard word ' $n$ gewelddadige handeling met ' $n$ soortgelyke of erger handeling beantwoord. Die een word dus soos die ander; die geweld word nageboots én vererger.

Adolessente het ' $\mathrm{n}$ besondere behoefte aan rolmodelle (Baumeister 1990:518-520). Hulle vind sodanige rolmodelle onder andere op televisie. Daar sien adolessente hoe helde optree wanneer hulle te na gekom word; daar aanskou hulle weerwraak, en aanvaar dus dat dit die korrekte optrede is Geweld boei die huidige samelewing. Daar is ' $n$ oorvloed geweld op televisie, en dít maak mense meer verdraagsaam teenoor geweldenaars. Deur gewelddadige televisieprogramme word kinders en adolessente herhaaldelik aan dade van wraak en weerwraak blootgestel. Tradisioneel word daar geglo dat die enigste bevredigende wraak vir bloedvergieting is om ook die moordenaar se bloed te vergiet. Hiervolgens is daar geen duidelike verskil tussen die daad waarvoor die moordenaar gestraf word, en die straf self nie. Wraak is eindeloos, want dit vereis weerwraak, en weerwraak vereis verdere weerwraak. Wraak word derhalwe ' $n$ herhalende proses. Wanneer geweld in 'n sekere deel van 'n gemeenskap voorkom, bedreig dit dus die hele gemeenskap. 'n Wraakhandeling kan 'n kettingreaksie ontketen wat noodlottige gevolge vir die samelewing kan inhou. Girard (1986:44) meen dat geweld aansteeklik is, en dat mense ' $n$ gewelddadige daad met ' $n$ soortgelyke of selfs erger daad beantwoord.

In dié verband dien Gilbert, Brown, Pinel en Wilson (2000:690$700)$ se navorsingsprojek oor geweldsverergering as voorbeeld. Die ondersoek begin met ' $n$ speletjie waar ' $n$ man sy vinger saggies teen ' $n$ ander man se vinger moet druk. Laagenoemde man het opdrag om ewe hard terug te druk. Die eerste persoon moes dan weer dieselfde mate van druk uitoefen, en so moes hulle aangaan. Hoewel die twee proefpersone probeer het om dieselfde druk uit te oefen, het hulle telkens $40 \%$ harder gedruk. Wat as 'n speletiie met sagte aanraking begin het, het vinnig in 'n spel met matige en later harder houe ontaard, ten spyte daarvan dat hulle telkens probeer het om sagkens te reageer. Elke deelnemer was oortuig dat hy met dieselfde krag reageer. Die pyn wat 'n mens ontvang, voel immers erger as die pyn wat jy uitdeel, en dus gee mense gewoonlik meer pyn as wat hulle ontvang. Dít lei tot die verergering van wedersydse geweldpleging, sowel as die illusie dat ander geheel en al daarvoor verantwoordelik is, en dat die eie reaksie dus regverdigbaar is (Gilbert et al. 2000:690-700).

Solank as wat haat en agterdog in ' $\mathrm{n}$ gemeenskap voorkom, sal geweld toeneem. Mense berei hulle op ander se moontlike aggressie voor, en vertolk sodanige voorbereidingsmaatreëls by ander as bevestiging van die ander se aggressie. Wanneer geweld eers in ' $n$ samelewing gevestig is, word dit moeilik omgekeer. Dit is derhalwe nodig om ál die vorms van geweld wat tot nabootsing kan lei te voorkom om hierdie bose kringloop van geweld te stop. Die American Academy of Pediatrics (2001:1222-1226) het die volgende statistiek ten opsigte van kinders en geweld vrygestel: Teen die tyd dat kinders 18 jaar oud is, het hulle reeds gemiddeld 200000 geweldsdade, wat 40000 moorde insluit, aanskou. Dít het tot gevolg dat kinders geweld as ' $n$ aanvaarbare manier van konflikbestuur beskou, omdat hulle gedesensiteer raak met betrekking tot geweld en geweldslagoffers

Volgens Girard (1986:182) het kulture geweld oor duisende jare heen deur middel van die sondebokmeganisme beheer. Dit is nie toevallig dat Jesus ' $n$ alternatiewe manier bied om geweld te oorkom nie. Die Bybel toon die algemene geweldspatrone, en bied dan 'n goddelike reaksie daarop. Jesus as rolmodel leer mense dat die boodskap van die evangelie liefde en vergifnis is. Hy stel voor dat mense die begeerte om te wil hê wat ander wil hê eerder weer op die oorspronklike doel van nabootsende begeerte toespits, naamlik om te wil wees soos God is. Mense behoort God dus as die eintlike rolmodel te kies en na te boots.

\section{Jesus as rolmodel}

Girard (1986:180) is van mening dat die gekruisigde en opgestane Jesus ' $n$ teenmiddel vir mimetiese geweld bied. Jesus het geweier om in die vernietigende maalkolk van geweld ingetrek te word. Selfs wanneer Jesus gewelddadig aan die kruis vasgespyker word, weier Hy om wraak te neem. Die opgestane Jesus tree met genade op: Hy bied God se nuwe skepping vir sy moordenaars aan. Hierdie nuwe skepping word in gemeenskappe vergestalt wat God se genade en vrede weerspieël. Pastors se taak is om getraumatiseerde adolessente te begelei om Jesus as rolmodel te kies; om Hom na te volg, en soos Jesus te word.

Jesus is veral 'n rolmodel wat vergifnis betref. Derhalwe word daar vervolgens oor die tema van getraumatiseerde adolessente en vergifnis besin. Volgens Girard (1986:156) het kennis van die sondebokmeganisme in samelewings nie tot minder geweld gelei nie, maar meen hy dat 'this knowledge must be added to the will to forgive'. Vergifnis is ' $\mathrm{n}$ belangrike sleutel vir mense wat die verskrikking van hulle verlede wil oorkom. Vanweë die Christelike opdrag om te vergewe, beleef getraumatiseerdes boonop ' $n$ 'teologiese trauma'; hulle word dus dubbele slagoffers. Hulle ervaar reeds skaamte en pyn oor wat hulle aangedoen is, maar verval selfs dieper in skuldgevoel omdat hulle nie die oortreder kan vergewe nie. Om vergifnis te ontvang, 'móét' hulle vergewe. Nederlandse praktiese teoloog Ruard Ganzevoort (2003:25) stel dit soos volg: '...dan lijkt het of slachtoffers naast de druk om te vergeven, ook nog de last van het uitblijven van Gods vergeving op hun schouders krijgen...'. Christie Neuger (2001:101), ' $\mathrm{n}$ pastorale teoloog en dosent by Brite Divinity School, is van mening dat pastors dikwels aan slagoffers die boodskap gee dat as hulle vergewe, hulle goeie Christene is. Hulle word daaraan herinner dat God alle sonde vergewe (kyk Ganzevoort 2003:55).

Wanneer vergifnis só 'n groot deel van die terapie uitmaak, word die slagoffer nogmaals tot magteloosheid gedryf. Die Franse filosoof Emmanuel Levinas (1978:45-46, eie vertaling) stel dit soos volg: " $n$ Wêreld waarin vergifnis almagtig geword het, word onmenslik.' Vergifnis kan heling in die hand werk nét indien die slagoffer dit vrywillig aanbied. Howard Stone (1994:76), 'n dosent in Pastoraat die Brite Divinity School, is van mening dat ' $n$ getraumatiseerde adolessent aangemoedig moet word om van bitterheid ontslae te raak ten einde heel te word, ongeag of die oortreder daarvoor vra of nie. Hy dui daarop dat misbruikers selde indien ooit om vergifnis vra. Sommige slagoffers meen dat hulle alleenlik kan vergewe indien die oortreder daarvoor vra, want die konsep van vergifnis berus daarop dat die oortreder die eerste tree na versoening gee (Stone 1994:76). As dít waar sou wees, sou die wêreld in bitterheid vasgevang wees. Hy meen dat vergifnis gegee behoort te word, selfs al is daar geen skuldbelydenis deur die oortreder nie. Volgens Dietrich Bonhoeffer is:

[t]rue repentance...embodied in a life of discipleship. Forgiveness is thus costly. Forgiveness cannot be demanded. It can only be hoped for. The aim of forgiveness is to restore communion with one another and with God in order to reconcile our brokenness. Forgiveness is a way of life.

(Bonhoeffer 1959:36)

Ganzevoort (2003:27) beskou vergifnis eerder as 'n innerlike verandering in die slagoffer se houding teenoor die oortreder. Die oortreder se skuld word erken, en die oortreding word geensins goedgekeur nie. Die band tussen die slagoffer en die oortreder word egter losgemaak. Ganzevoort stel dit soos volg:

De dader is niet langer door middel van schuld met het slachtoffer verbonden. Het slachtoffer ziet onder ogen dat zij slachtoffer is en laat dan het slachtofferschap achter zich. Er is sprake van het doorbreken van een machtsrelatie.

(Ganzevoort 2003:28)

Die getraumatiseerde spreek dus die oortreder vry, sodat die 
getraumatiseerde self ook vry kan word. Neuger (2001:222) beskryf vergifnis in hierdie verband soos volg: '...letting go of the immediacy of the trauma, the memory of which continues to terrorize the victim and limit possibilities'. Neuger is van mening dat vergifnis die laaste stap in die helingsproses is:

After a former victim is safe from violence, after she has grieved the many losses caused by her experience of violence, after she has reorganized her life to the way she wants it to be, after she has gained inner strength and a relationship with God, then the word of forgiveness can be considered.

(Neuger 2001:101)

Hierdie laaste stap in die helingsproses kan slegs geskied wanneer die slagoffer reg is daarvoor:

Forgiveness must be carried out according to the trauma survivor's timetable. This is not a step that can be hurried along. Only the trauma survivor her or himself truly knows when that time is right

(Neuger 2001:159)

Dat vergifnis belangrik is wanneer daar met getraumatiseerdes gewerk word, betwyfel Neuger (2001:112) nie: 'Part of this research journey for me has been a realization of the importance of forgiveness in terms of healing from the effects of trauma.'

Latere samelewings het probeer om die kringloop van wraak en die bygaande geweld te stop deur ' $n$ regstelsel in te stel. Hierdie stelsel skakel nie wraak uit nie, maar beperk dit bloot tot ' $n$ enkele daad van weerwraak deur 'n gesag wat bepaald vir hierdie doel ingestel is. Die regbank het die laaste sê, en verhinder dat verdere geweld volg. Getraumatiseerde adolessente behoort begelei te word om die regstelsel te gebruik om 'n einde aan geweldpleging te bring, eerder as om weerwraak uit te oefen. Dít word egter 'n probleem wanneer die regstelsel nie doeltreffend is nie. Suid-Afrika het onder andere die hoogste verkragtingsyfer ter wêreld (120 verkragtings per 100000 inwoners), en baie van die verkragtings word deur paroolgangers gepleeg wat al voorheen aan verkragting skuldig bevind is. Hoewel verkragting nie ' $n$ wraakmisdaad is nie, is daar wel geweld ter sprake (vgl. ISS [Instituut vir Sekerheidstudies] Graphs of SAPS crime statistics 1994-2000).

Indievroegstegemeenskappeisgeweldsvoorkomingbeklemtoon omdat geweld so vinnig toegeneem het en so moeilik gestuit word. Geweldsvoorkoming het suiwer op godsdienstige gebied geval. Só was dit oor duisende jare heen deel van die taak van godsdiens om 'n gees van niegewelddadigheid in gemeenskappe te probeer vestig. Soms het godsdienste self klaaglik misluk, en het geweld juis binne en tussen godsdienste gedy.

\section{DIE SONDEBOKMEGANISME}

\section{Die funksie van 'n 'sondebok'}

Wanneer ' $n$ mens geweld ontleed, kan die sondebok maklik geëien word. Die teorie oor die sondebokmeganisme bied insigte oor hoe mense geweld verwerk deur iemand óf iets te blameer. Deur die blootlegging van die sondebokmeganisme wil Girard beter begrip van traumahantering by mense in die hand werk.

In sy bespreking van die sondebokteorie wys Girard (1986:14) daarop dat die vroegste samelewings tot stand gekom het nadat mense herhaaldelik in geweldsituasies ' $n$ sondebok geoffer het. Ná die offer het daar dan verandering gekom, en het die mense weer vrede ervaar. Die hominiede (eerste mensagtige wesens) het mekaar se geweld nageboots. Dit kan as geweld déúr almal téén almal beskryf word. In 'n sekere stadium is die oplossing egter spontaan ontdek toe die geweld, in plaas van op die gemeenskap in die algemeen, net op een sondebok in die besonder gemik is. 'n Enkele individu het dus die skuld vir alle probleme gekry, en moes daarvoor met sy/haar lewe boet. Dat dít as oplossing vir algemene geweldpleging sou dien en tot vrede sou lei, was deel van 'n onbewuste proses.

Dié ritueel kon egter net doeltreffend wees as die gemeenskap nie die sondebok as slagoffer beskou het nie. In die oë van die gemeenskap moes die sondebok boos en sleg wees - iemand wat die dood verdien. Terwyl die beskuldigde dalk gedeeltelik vir die geweld in die gemeenskap verantwoordelik was, het die gemeenskap hom/haar van alles wat verkeerd is beskuldig.

Ná hierdie gesamentlike moord op die sondebok het die geweld déúr almal téén almal tot ' $n$ einde gekom. Die moord op, of uitdryf van, die sondebok het die gemeenskap verenig, waarná hulle 'n 'oomblik van ontsag', wat Girard (1987:34) 'n 'gewyde oomblik' noem, beleef het. Dít was ' $n$ magiese vrede. Op hierdie wyse is geweld déúr almal téén almal tot onderlinge eenheid in die gemeenskap omvorm. Die geweld is uitgewoed. Rondom die lyk van die slagoffer ervaar die gemeenskap die vrede wat hierdie daad gebring het. Die slagoffer kry nou 'n soort magiese krag. Volgens Girard (1986:146) het die eerste samelewings deur sulke sondebokrituele tot stand gekom. Wanneer geweld weer opvlam, soek hulle bloot weer 'n sondebok, en die wonderlike oomblik van vrede en eenheid word herhaal. Só het dit ' $n$ gewyde ritueel met plaasvervangerslagoffers geword: '...new victims for the original victim, in order to assure the maintenance of that miraculous peace' (Girard 1986:202). Die naïewe godsdienstige vertolking van die hele gebeurtenis wat hom geleidelik om hierdie gesamentlike moord afspeel, is dat die gemeenskap deur ' $n$ godheid besoek is wie se bonatuurlike magte eers chaos en toe magiese vrede gebring het.

Die oombliklike staking van die geweld wat die gesamentlike moord meegebring het, noem Girard (1986:198) die 'sondebokeienskap'. Hy meen dat 'n lang reeks moorde wat herhaaldelik oor moontlik 'n miljoen jaar gepleeg is die vroeë mense in die loop van evolusie geleer het dat die dood van een of meer lede van die groep ' $n$ onverklaarbare vrede bring. Hierdie patroon lê ten grondslag aan Girard se sondebokteorie.

Die sondebokeienskap het by talle samelewings voorgekom, en daarom betoog Girard dat dit ' $n$ algemeen menslike eienskap is. 'Goeie' geweld is op hierdie wyse gebruik om 'slegte' geweld uit die gemeenskap te verdryf (Girard 1986:12). Girard (1986:200) meen dat die menslike kultuur só saamgestel is, en dat godsdiens die kern daarvan uitmaak.

Getraumatiseerde adolessente se soeke na 'n sondebok

Getraumatiseerde persone voel waardeloos, en kan hulle nie laat geld nie. Hulle selfbeeld is aangetas deur vernedering, skuld en magteloosheid. Omdat die tienerjare die tyd is waarin mense hulle identiteit ontdek, het trauma gedurende hierdie fase ' $n$ negatiewe uitwerking op identiteitsvorming. Die brein is besig om die trauma te probeer hanteer en verwerk, en te min energie word dus aan die ontwikkelingstaak van identiteitsvorming bestee. Só ' $n$ adolessent is dus natuurlik daartoe geneig om ' $n$ sondebok te probeer vind. ' $n$ Maklike teiken is die adolessent self, en daarom blameer hulle hulleself vir die trauma, selfs al is daar geen rasionele verband nie. Soms soek hulle egter ook na ' $n$ sondebok buite hulleself. Hulle is byvoorbeeld kwaad vir reddingsorganiseerders, die regering of mediese dienste wat volgens hulle die trauma kon verhoed het, of vinniger op die trauma moes gereageer het (Hodgkinson \& Stewart 1991:57). Hulle voel beter wanneer hulle ' $n$ sondebok gekry het. Dikwels is sulke adolessente ook kwaad vir God wat hulle nie teen die trauma beskerm het nie. Woede speel ' $n$ belangrike rol in die gebruik van die sondebokmeganisme. Woede lei byvoorbeeld daartoe dat getraumatiseerdes ' $n$ sondebok soek, want as hulle eers een gevind het, kan die woede bedaar. Woede by kinders en adolessente gee uiting aan onderliggende hartseer, verlies, magteloosheid, vrees en angs. Dit is dikwels vir ' $n$ kind makliker om die woede-emosie te beleef as om aan die pynliker onderliggende emosies uiting te gee (Hodgkinson \& Stewart 1991:59).

Volgens Lifton (1983:2-6) voel getraumatiseerde adolessente dikwels dat ander hulle nie verstaan nie, omdat sodanige ander nie die trauma self beleef het nie. Soms neem hulle mense kwalik wat nie ook soos hulle getraumatiseer is nie. Hulle vind 
slegs vertroosting by mense wat deur 'n soortgelyke trauma is. Dikwels bespreek hulle nie die trauma met familielede nie, en laat dít die familielede uitgesluit voel (Miller 1998:76).

Kinders is in die algemeen nog nie in staat om op 'n gepaste manier aan hulle woede uiting te gee nie. Wanneer hulle dit wél regkry, dui dit daarop dat die genesingsproses goed vorder. Getraumatiseerde mense het die reg om woede te beleef as gevolg van wat met hulle gebeur het, en het eweneens die reg om daaraan uiting te gee. Getraumatiseerde adolessente het 'n behoefte om van hulle pyn bevry te word, en soek daarom onbewus na 'n gepaste sondebok. Die traumaslagoffer blameer die sondebok, en pleeg op dié manier geweld teenoor die sondebok, wat op sý beurt nou tot slagoffer gemaak word. Deur die 'slagoffer' (sondebok) te blameer, genees die 'oortreder' (traumaslagoffer) die skade aan sy/haar eie psige.

Die soeke na 'n sondebok is 'n onbewuste daad. Sodra 'n sondebok gevind is, is dit asof getraumatiseerdes makliker met die trauma vrede maak. Familielede van getraumatiseerdes is ook geneig om 'n sondebok te soek wat die skuld vir die trauma kan dra. Pastors se taak is om getraumatiseerdes te help om aan hulle gevoelens uiting te gee sonder dat dit ander (dikwels gesinslede) seermaak.

Omdat trauma ook tot selfverwyt kan lei, behoort pastors adolessente te begelei om hierdie emosies as die gevolg van irrasionele denke, wat op onrealistiese inligting gegrond is, te beskou (Figley 1978:18). Getraumatiseerde mense voel soms skuldig omdat hulle bly leef het en ander nie (Lifton \& Olson 1976:1-18). Hulle verwyt hulleself omdat hulle nie méér gedoen het om persone wat in ' $n$ traumatiese gebeurtenis gesterf het te help nie. Só maak hulle hulleself tot sondebok. Jonger kinders voel dikwels skuldig omdat hulle dink dat hulle slegte gedrag vir die trauma verantwoordelik was (Van der Kolk 1991:91).

Baie oorlewendes van seksuele misbruik en akute trauma ontwikkel kroniese angs en depressie wat tot in hulle volwassenheid kan voortduur (Browne \& Finkelhor 1986:6677). Mishandelde en getraumatiseerde kinders en adolessente ontdek in ' $\mathrm{n}$ stadium dat dié gevoel doeltreffend beëindig kan word deur hulleself te beseer. Hulle verklaar hulleself onbewus tot sondebok. Die dramatiesste metode om hierdie resultaat te verkry, is deur hulleself te sny. Kinders wat misbruik is, ontwikkel dikwels die gewoonte om hulleself herhaaldelik te beseer. Hoewel 'n groot getal oorlewendes van kindermisbruik uiteindelik selfmoord pleeg, is daar 'n duidelike onderskeid tussen herhaaldelike selfbesering en selfmoordpogings. Selfbesering is nie veronderstel om dood te maak nie, maar eerder om onuithoudbare emosionele pyn te probeer verlig (Herman 1992:109). Bulimie, kompulsiewe seksuele gedrag, kompulsiewe risikogedrag, blootstelling aan gevaar, en die gebruik van psigo-aktiewe dwelms is ' $n$ paar maniere waarop misbruikte en getraumatiseerde kinders en adolessente hulle emosies probeer hanteer (Herman 1992:109).

\section{Die profiel van 'n sondebok Fisieke kenmerke}

Volgens Girard (1977:31) toon die slagoffer wat as sondebok gekies word sekere eienskappe. Die slagoffer is swakker as, of verskil van, die res. 'n Belangrike kenmerk van die slagoffer is dat hy/sy aan geweld blootgestel kan word sonder dat mense weerwraak hoef te vrees. 'n Offer is ' $n$ geweldsdaad sonder die risiko van verdere geweld. Adolessente voldoen aan sekere eienskappe wat hulle meer geskik maak om as sondebok aangewys te word. Hulle word maklik vasgevang in die sondebokmeganisme, omdat hulle selfbeeld nog weerloos en vormbaar is. Daarom kyk hierdie artikel vervolgens na die identiteitsverwerwing van adolessente, en toon voorts waarom adolessente hulleself so maklik tot sondebok gemaak word.

Adolessente se fisieke kenmerke en voorkoms het ' $\mathrm{n}$ beduidende invloed op hulle selfbeeld (Richards 1985:52). Enige afwyking van die gangbare norm kan angs en onsekerheid veroorsaak, en 'n negatiewe invloed op adolessente se selfbeskouing hê (Richards 1985:53). Dít bring mee dat hulle maklike teikens is om hulleself tot sondebok te verklaar. Trauma veroorsaak dat hulle met probleme moet worstel waarvoor hulle nie gereed of op voorbereid is nie. Trauma veroorsaak verwarring, en dié verwarring maak hulle des te meer maklike teikens om tot sondebok verklaar te word. Adolessente se liggaamlike verandering raak hulle selfbeeld, wat nou gewysig moet word om by die veranderinge aan hulle lyf aan te pas. Vanweë liggaamsveranderinge is hulle vorige liggaamsbeeld nie meer voldoende nie. Veral hulle nuut verworwe geslagsrypheid moet in hulle selfbeeld opgeneem word. Hulle kyk besonder krities na hulle lengte, massa en gelaatskleur. Indien dit nie na hulle $\sin$ is nie is hulle tydelik verward ten opsigte van hulle selfbeeld, en verloor hulle hulle selfvertroue. Om vir hulle gebrek aan selfvertroue en negatiewe selfbeeld te vergoed, tree hulle dikwels rebels en grootdoenerig op (Smith 1981:32). Gewigstoename kom veral by meisies voor, en dit pla hulle baie (Elium \& Elium 1996:316). As gevolg van die belang van die fisieke vir adolessente is hulle selfbeeld besonder weerloos, en word hulle maklik in die sondebokmeganisme vasgevang.

\section{Erikson se teorie oor identiteitsvorming}

Erik Erikson (1968:13-55) het 'n teorie geformuleer wat van groot belang is vir die ontwikkeling van die mens. Sy teorie word as psigososiaal beskryf omdat hy die wisselwerking tussen die persoon se innerlike eienskappe, en die eise van die kultuur en samelewing beklemtoon (Gerdes 1988:73). Volgens Erikson bestaan daar 'n grondplan waarvolgens psigologiese ontwikkeling in agt opeenvolgende stadia ontvou. In elke stadium word individue voor die uitdaging gestel om ' $n$ bepaalde krisis op te los, en daarná na 'n volgende ontwikkelingstadium én die volgende krisis aan te beweeg. Elke krisis vereis die ontwikkeling van ' $n$ bepaalde vaardigheid; indien die vaardigheid nié aangeleer word nie sal dit verdere ontwikkeling belemmer, aangesien die vaardigheid nie bemeester is nie (Erikson 1968:14-20). Bevredigende leer en krisisoplossing is nodig voordat die kind na ' $\mathrm{n}$ volgende ontwikkelingsfase kan aanbeweeg. Erikson se ontwikkelingsfases is soos volg:

- Vertroue teenoor wantroue (0-2 jaar)

- Outonomie teenoor skaamte (2-4 jaar)

- Inisiatief teenoor skuld (4-6 jaar)

- Arbeidsaamheid teenoor minderwaardigheid (6-12 jaar)

- Identiteitsverwerwing teenoor identiteitsverwarring (13-20 jaar)

- Intimiteit teenoor isolasie

- Generatiwiteit teenoor stagnasie

- Ego-integriteit teenoor wanhoop.

Vervolgens sal die adolessentfase bespreek word om te toon dat adolessente maklik in die sondebokmeganisme vasgevang word omdat hulle selfbeeld nog baie weerloos en vormbaar is.

Erikson beskou adolessensie as baie belangrik vir psigososiale ontwikkeling, veral omdat dit as grondslag vir die daaropvolgende ontwikkeling gedurende volwassenheid dien. Erikson is van mening dat die mees deurslaggewende tydperk in die vorming van die volwassene se persoonlikheid die adolessensiejare is (Erikson 1968:88). Gedurende adolessensie is dit individue se hooftaak om op grond van wat hulle oor hulleself en ander geleer het 'n eie identiteit te ontwikkel. Indien hulle nie hierin slaag nie lei dit tot roldiffusie (rolverstrooiing) hulle beleef dus onsekerheid oor hulleself, hulle rolle, en hulle plek in die samelewing. Hierdie onsekerheid maak hulle vatbaar daarvoor om in die sondebokmeganisme vasgevang te word. Adolessente sal geleidelik nuwe moontlikhede verken om beter te kan funksioneer. Die ontwikkeling van 'n rol-identiteit sal meer moontlikhede vir sosiale betrokkenheid en die abstrakte konseptualisering van trauma bied.

Om hulle identiteitskrisis op te los, moet adolessente volgens Erikson (1968:59) deur 'n oorgangstadium gaan waar individue 
min verpligtinge het, en in staat is om te soek, te bevraagteken, en met verskillende rolle en geloofstelsels te eksperimenteer. Hulle kan byvoorbeeld met verskillende beroepsrolle eksperimenteer deur verskillende soorte vakansiewerk te doen. Gedurende hierdie tydperk kry individue die geleentheid om te eksperimenteer sonder dat daar noodwendig van hulle verwag word om te slaag. Mislukking in hierdie stadium hoef nie noodwendig ernstige emosionele, ekonomiese en sosiale gevolge te hê nie. Met die verloop van die adolessentejare begin adolessente betekenisvolle ander persone se mening by hulle eie voorkeure en afkeure integreer

Op hierdie wyse begin hulle ' $n$ eie identiteit ontwikkel (Erikson 1968:56-99). Antwoorde op die vraag 'Wie is ek?' begin vorm aanneem wanneer adolessente die oortuigings, houdings en waardes begin ondersoek wat hulle voorheen bloot aanvaar het deur hulle met ander te vereenselwig, maar wat hulle nou nie meer met hulle eie behoeftes en houdings kan versoen nie. Hulle behou daardie aspekte wat inpas, en integreer dit by hulle eie persoonlikheid om ' $n$ unieke geheel te vorm. Geslaagde identiteitsvorming vind plaas wanneer adolessente vir hulleself kan sê: 'Dít is waarin ek belangstel en waaraan ek waarde heg'; wanneer hulle weet wat hulle van die lewe verwag, waar hulle by die samelewing inpas, en wat ander van hulle verwag. Word hierdie tydperk van eksperimentering egter onbepaald voortgesit, kan dit tot ' $n$ onvermoë lei om volwasse verantwoordelikhede te aanvaar (Gerdes 1988:74), en sou dit adolessente verder daarvoor vatbaar maak om hulleself tot sondebok te verklaar.

Die proses van identiteitsontwikkeling begin reeds in die vroeë kinderjare, maar word gedurende adolessensie ' $n$ ontwikkelingskrisis wat opgelos moet word indien ' $n$ kenmerkende identiteit tot stand moet kom. Indien adolessente nie daarin slaag om hulle identiteit duidelik te omskryf nie, sal rolverwarring en identiteitsonsekerheid in die weg staan van ' $n$ verbintenis tot volwasse en langtermynrolle, en sal dít adolessente ook meer geneig maak om die sondebokmeganisme toe te pas. Daar is goeie redes waarom adolessente se identiteit deur adolessensie verander. Omdat fisieke verandering so vinnig en drasties plaasvind, verander dit die fisieke self, oftewel adolessente se siening van hulle eie liggame.

Erikson (1968) meen dat indien 'n gevoel van individuele identiteit gedurende adolessensie gevorm word, dit gedurende vroeë volwassenheid gestabiliseer word. Dít vind plaas wanneer persone se belangstellings verdiep en minder veranderlik is; wanneer hulle vermoëns om te werk en lief te hê deur verantwoordelike betrokkenheid by ' $n$ beroep en by die vorming van ' $n$ gesin bevestig word; wanneer hulle die geleentheid het om hulle idees te toets en te bevestig.

Onlangse studies bevestig Erikson se beskouing dat die bevraagtekening van ' $n$ mens se waardes, planne en prioriteite noodsaaklik is vir die vorming van ' $n$ volwasse identiteit. Die navorsers in dié studies bestempel egter nie meer soos Erikson hierdie proses as ' $n$ krisis nie (kyk Brownlee I999:15; Beautris 2002:77). Trauma lei die aandag weg van identiteitsvorming, en só verbeur adolessente die geleentheid om deur rolverwarring te werk. Hierdie verwarring (trauma-, liggaams- én rolverwant) veroorsaak hartseer, onsekerheid, magteloosheid, vrees en angs. Adolessente steek dit agter woede weg, omdat woede' $n$ makliker emosie is om te hanteer. Om dié woede te verwerk, moet hulle 'n sondebok soek op wie hulle die woede kan projekteer. Dié sondebok is dikwels hulleself, juis omdat hulle so magteloos en onseker voel.

\section{Emosionele ontwikkeling}

Kenmerkend van adolessente se emosionele lewe is die komplekse en intense aard daarvan. Verhoogde emosionaliteit in die vorm van buierigheid, bakleierigheid en emosionele uitbarstings kom dikwels voor (Smith 1981:32).
Die jare van liggaamlike veranderinge gaan met skommelende gevoelens gepaard wat die adolessent kwalik verstaan. Die meeste adolessente toon kenmerke van innerlike verwarring, wat met gemoedskommeling gepaardgaan (Richards 1985:56). Trauma veroorsaak óók veranderde emosies, en daarom beleef adolessente inderwaarheid van twee kante af onbegryplike emosies. Om dít te hanteer, moet hulle een emosie uitsonder, en gewoonlik is dit woede. Om woede te hanteer, moet hulle 'n sondebok vir die trauma vind. Hulle emosies word deur verskeie faktore beïnvloed. Sulke faktore is hoofsaaklik in mense en situasies geleë. Die nuwe aanpassings wat hulle as adolessent in die volwasse wêreld moet maak, is belangrike oorsake van verhoogde emosionaliteit. Volwassenes verwag van adolessente om selfstandig op te tree deur byvoorbeeld hulle emosies in toom te hou - iets waartoe adolessente dikwels nie in staat is nie.

Om ' $n$ verhouding met die teenoorgestelde geslag aan te knoop, bring dikwels spanning en algemene opwinding mee (Smith 1981:35). Ander faktore wat hulle emosies verhewig, is hulle beroepskeuse, uitermatig streng optrede deur hulle ouers, en seksuele rypwording. Hulle beleef allerhande nuwe gevoelens wat hulle nie altyd kan begryp en hanteer nie. Gevoelens oor seksuele sake is veral vir hulle moeilik hanteerbaar.

Gedurende vroeë adolessensie (13-16 jaar) kyk adolessente deur 'n rooskleurige bril na die wêreld. Hulle verwag om skoonheid en volmaaktheid te sien, maar vind in plaas daarvan net onregverdigheid en menslike tekortkomings. Hierdie realiteite laat hulle gefrustreerd, onseker en ontnugter. Dit kan hulle selfs sinies maak (Elium \& Elium 1996:257). Daarom is trauma vir hulle ' $n$ besondere ontwrigting wanneer dit deur mense veroorsaak word - mense wat ander opsetlik leed aandoen.

Adolessente is meestal nog nie emosioneel ryp nie, en het in die algemeen nie volle beheer oor hulle emosionele wêreld nie. Hulle word maklik deur emosies meegesleur (Smith 1981:35). Hulle het ook nog nie die balans tussen rasionele denke en emosies gevind nie. Dit is nie 'rasioneel' en emosioneel volwasse om ' $n$ sondebok te soek nie - die volwasse ekwivalent is veel eerder die opbouende verwerking van emosies. Adolessente het egter nog nie daardie balans gevind nie, en verval dus maklik in die gebruik van die sondebokmeganisme.

Ná ' $n$ traumatiese gebeurtenis wantrou mense ander én hulleself. Hulle sukkel soms jare lank om vertroue in die wêreld en mense te herwin (Matasakis 1996:100). Dít werk daartoe mee dat hulle 'n sondebok soek, want wanneer hulle 'n sondebok gevind het, kan hulle die res van die wêreld weer makliker vertrou. Volgens Girard (1986:146) het die eerste samelewings juis 'n sondebok gesoek wanneer geweld opgevlam het. Nadat die sondebok geoffer is, kon hulle ' $n$ wonderlike oomblik van vrede en eenheid beleef. Só bring 'n sondebok vir getraumatiseerdes vrede, en kan getraumatiseerdes weer die wêreld vertrou.

\section{Misverstande oor die sondebokritueel}

Wat die sondebokritueel betref, verstaan die gemeenskap dikwels twee bepaalde sake verkeerd. Die eerste misverstand is dat die vrede wat hulle ná die ritueel beleef direk deur die slagoffer meegebring word (Girard 1986:210). Die tweede is dat ál die geweld die slagoffer se skuld was. Hierdie misverstande verleen aan die slagoffer die mag oor geweld én vrede. In die vroeë gemeenskappe is dít as ' $\mathrm{n}$ goddelike eienskap beskou. Dít word ook die oorsprong van die vroeë godsdiens (Girard 1986:210). Indien die gemeenskap sou kon begryp dat die oorsprong van die 'gewyde ritueel' die moord op 'n betreklik onskuldige persoon was wat willekeurig aangewys is, sou dit nie dié uitwerking van ontsag gehad het nie. Die ritueel was die poging om die gewyde gebeure op ' $n$ beheerde manier uit te voer, sodat die gevoel van ontsag en vrede verkry kon word sonder om deur die chaos van geweld te moes gaan. Op dieselfde manier sal getraumatiseerdes nie werklik beter voel nadat hulle 'n sondebok gevind het, of hulleself tot sondebok gemaak het, 
indien hulle begryp dat die sondebok eintlik onskuldig is, of dat ál die oorsake van die geweldsdaad nie werklik op net een persoon afgeskuif kan word nie.

\section{Jesus as 'sondebok'}

Volgens Girard (1987:44-98) vertel die Bybel, en spesifiek die evangelies, die eerste keer die verhaal van geweld teen die sondebokslagoffer vanuit die hoek van die slagoffer, en nie soos die meeste mites vanuit die perspektief van die gemeenskap nie. Deur op die slagoffer eerder as op die 'regverdigbare geweld' teen die slagoffer te konsentreer, word die sondebokmeganisme onderliggend aan die gewyde mites blootgelê. Wanneer dít ontmasker word, word die mag van die sondebokmeganisme verswak en ondermyn. Girard stel dit soos volg:

Once understood, the mechanism can no longer operate, we believe less and less in the culpability of the victims they demand. Deprived of the food that sustains them, the institutions collapse one after the other around us. Whether we know it or not, the Gospels are responsible for this collapse.

(Girard 1987:44)

Girard (1987:50) se sondebokteorie toon dat gemeenskappe tot en met die tyd van Jesus geweld deur middel van die sondebokmeganisme beheer het. As gevolg van die vrees en wraak van mense is Jesus as onskuldige slagoffer vermoor. Met Jesus se lewe en dood word die sondebokteorie ontmitologiseer. Dit is nie God wat verwag dat 'n onskuldige persoon moet sterf nie, maar ander magte wat ' $n$ offer vereis, en dié vereiste dan aan God toedig. Die dood van die sondebok is selfs nog in Jesus se tyd as ' $n$ offer beskou. Dít is wat die hoëpriester Kajafas met die volgende woorde bedoel het: '...en julle besef ook nie dat dit tot julle voordeel is dat een man vir die volk sterwe en nie die hele nasie verlore gaan nie' (Joh 11:50). Jesus het verstaan dat God die bron van onvoorwaardelike liefde en absolute vergifnis is, en dít sluit volgens Girard (1987:77) die moontlikheid uit dat God die offer van ' $n$ onskuldige sou eis. Deur die werklike betekenis van die sondebokmeganisme bloot te lê, word Jesus se dood die finale offerande, en dui dit die einde van alle offers aan. Girard (1987:80) beskou Christus as 'n 'nuwe soort sondebok' - een wat homself offer en daardeur toon dat hy verstaan wat aan die gebeur is. Die woorde 'Vader, vergewe hulle, want hulle weet nie wat hulle doen nie' is in dié verband vir Girard die kern. Die klimaks is nie die dood van die slagoffer nie, maar die ervaring van gewyde ontsag wanneer die slagoffer met sy dood sy folteraars vergewe. Girard (1987:90) heromskryf Jesus se dood as 'n selfoffer om vir die wêreld te wys dat die sondebokmeganisme ' $n$ vergeefse poging is om geweld te beëindig.

Teologies en histories beskou, stel Jesus se dood volgens Girard (1986:99) die sondebokmeganisme aan die kaak, en wis dit gevolglik uit. Deur die eeue heen het die uitwerking van die evangelie op die kultuur grootliks die mag van die sondebokmeganisme ondermyn. God beantwoord die mens se geweld met niegewelddadige liefde, en volgens Girard (1987:89) is dít die kern van die Bybelse boodskap. Vir hom is dit betreurenswaardig dat hierdie boodskap deur die geskiedenis van die kerk heen grootliks geignoreer is. Die kerk het volgens hom die dood van Christus verkeerd vertolk deur te verkondig dat God 'n offer, 'n slagoffer, geëis het. Volgens Bailie (1995:2), wat Girard se teorie op hedendaagse geweld toepas, gee die Nuwe Testament ' $n$ stem aan die slagoffer. Die verhaal word vanuit die slagoffer se perspektief vertel. Hierdie boodskap kan met groot vrug deur die pastor gebruik word in die begeleiding van getraumatiseerde adolessente wat 'n sondebok soek vir die onreg wat hulle aangedoen is.

\section{LITERATUURVERWYSINGS}

American Academy of Pediatrics 2001, Media violence, Pediatrics, 108, November, pp. 1222-1226.

Bailie, G., 1995, Violence unveiled: Humanity at the crossroads, Crossroad, New York.

Baumeister, F.R.F., 1990, 'Identity crisis', in R.M. Lerner (red.), The encyclopedia of adolescence (1), 518-521.
Beautris, A., 2002, 'Life events and childhood morbidity: A prospective study', Pediatrics, 935-940.

Bonhoeffer, D., 1959, The cost of discipleship, SCM, Londen.

Browne, Q. \& Finkelhor, D., 1986, 'Impact of child sexual abuse: A review of the research', Psychological Bulletin 99, 66-77.

Brownlee, B., 1999, Inside the teen brain. US News $\mathcal{E}$ World Report, 9, Augustus.

U.S. Department of Justice, Office of Justice Programs, Bureau of Justice Statistics Crime \& Justice Data Online 1973-2006, besigtig 25 Januarie 2008, by http://www.ojp.usdoj.gov/ bjs/.

Elium, D. \& Elium, J., 1996, Raising a son, University of California Press, Berkeley.

Erikson, E., 1968, Identity: Growth and crisis, Faber, Londen.

Figley, C.R., 1978, Stress disorders among Vietnam veterans: Theory, research, and treatment, Brunner/Mazel, New York.

Ganzevoort, R.R., 2003, Vergeving als opgave, KGSV, Tilburg.

Gerdes, L.C., 1988, Die ontwikkelende volwassene, Butterworths, Durban.

Gilbert, D.T., Brown, R.P., Pinel, E.C.\& Wilson, T.D., 2000, ‘The illusion of external agency', Journal of Psychology and Social Psychology 79, 690-700

Girard, R. 1965, Deceit, desire and the novel: Self and other in literary structure, John Hopkins University Press, Stanford.

Girard, R., 1977, Violence and the Sacred, John Hopkins University Press, Stanford.

Girard, R., 1978, To double business bound: Essays on literature, mimesis and anthropology, John Hopkins University Press, Stanford.

Girard, R., 1979, 'Mimesis and violence: Perspectives in cultural criticism', Berkshire Review 14, 9-19.

Girard, R., 1986, The scapegoat, John Hopkins University Press, Stanford.

Girard, R., 1987, Things hidden since the foundation of the world, Stanford University Press, Stanford.

Girard, R., 1993, 'Violence, difference, sacrifice: A conversation with René Girard', Religion and Literature 25, 9-33.

Herman, J.L., 1992, Trauma and recovery, Basic Books, New York.

Hodgkinson, P.E. \& Stewart, M., 1991, Coping with catastrophe, Routledge, New York.

ISS [Instituut vir Sekerheidstudies] Graphs of SAPS crime statistics 1994-2000, 1994-2004/Criminal Justice Monitor, SAPS Crime Statistics 1994-2004, released on 20 September 2004, besigtig 26 Augustus 2009, by http://www.iss.co.za/ $\mathrm{CJM} /$ statgraphs/index.htm

Levinas, E., 1978, Existence and existents, vertl deur A. Lingis, Martinus Nijhoff, Den Haag.

Lifton, R.J. \& Olson, E., 1976, 'The human meaning of total disaster', Psychiatry 39, 1-18.

Lifton, R.J., 1983, 'Responses of survivors to man-made catastrophes', Bereavement Care 2, 2-6.

Matasakis, A., 1996, Post-Traumatic Stress Disorder - a complete treatment guide, New Harbinger Press, Oakland.

Matasakis, A., 1996, I can't get over it, New Harbinger Publications, Oakland.

Miller, T.W., 1998, Children of trauma, International Universities Press, Connecticut.

Neuger, C.C. 2001, Counseling women: A narrative, pastoral approach, Fortress, Minneapolis.

Reinherz, H.Z., Giaconia, R.M., Lefkowitz, E.S., Pakiz, B. \& Frost, A.K., 1993, 'Prevalence of psychiatric disorders in a community population of older adolescents', Journal of the American Academy of Child and Adolescent Psychiatry 32, 369377.

Richards, L., 1985, Youth ministry, Zondervan, Grand Rapids. Smith, R., 1981, Leer die kind ken, Academica, Pretoria.

Stone, H., 1994, Brief pastoral counseling, Fortress Press, Minneapolis.

Van der Kolk, B.A., 1985, 'Adolescent vulnerability to Posttraumatic Stress Disorder', Psychiatry 48, 365-370.

Van der Kolk, B.A., 1991, 'Childhood origins of self-destructive behavior', American Journal of Psychiatry 148, 1665-1671. 